\section{El viraje de la ola. \\ Las primeras discusiones \\ sobre la intervención del Estado \\ en el socialismo argentino}

Mariana Luzzi
María Inés Luzzi es Becaria de Formación de Posgrado, CONICET, Instituto de Investigaciones Gino Germani, Universidad de Buenos Aires, Pte. José E. Uriburu 950, $6^{\circ}$ Piso, Ciudad de Buenos Aires, Tel. (011) 4508-3815, Fax (011) 4508-3822.

Email: marluzzi@yahoo.com

\section{Resumen}

El presente trabajo se propone reconstruir una parte de las discusiones que tuvieron lugar en la Argentina alrededor de la crisis de 1930, a propósito de las relaciones entre el Estado y la sociedad, y del papel que aquél debería cumplir en relación con la economía. Específicamente, busca abordar las propuestas y debates que en este sentido surgieron desde el pensamiento socialista argentino en la primera mitad de la década del '30.

Este objetivo es desarrollado en dos instancias diferentes. En primer lugar, se da cuenta de las propuestas concretas de política económica intervencionista surgidas desde el socialismo durante el período. En segundo término, se exploran las discusiones que dentro del espectro del pensamiento socialista del momento tuvieron lugar en torno a estas cuestiones. Para ello, se toman como referencia los debates y propuestas expuestos en la revista Claridad entre los años 1932 y 1936, considerando que, dado que dicha publicación fue tanto un espacio vinculado (aunque no orgánicamente) al Partido Socialista Argentino como un ámbito de debates de un espectro más amplio de la izquierda socialista argentina, permitirá una aproximación a las discusiones buscadas.

\section{Summary}

This article intends to reconstruct part of the debates that took place in Argentina just after the economic breakdown of 1930 about the links between State and Society, and specially about the role that the former should play in relation to the Economy. Our main purpose is to show the issues and agenda on these subjects that arose within the Argentinian socialist thought during the beginning of the thirties.

We intend to pursue our aim in two different means. First of all, we will look for socialist proposals for interventionist economic policies during the 1930s. Secondly, we will analyze the discussions about this subject in the Socialist thought in those times in Argentina. Therefore, we will examine the debates and contributions published between 1932 and 1936 by the Revista Claridad, as we consider the latter both a magazine related to the Argentine Socialist Party and a channel of expression of a wider branch of Argentinian Left. 